\title{
China's Income Distribution System Reform and Income Growth Strategy
}

\author{
Jiancheng Liu \\ Dongfang Boiler Co., Ltd., Zigong, China \\ Email: decljc@163.com
}

Received 16 April 2016; accepted 13 May 2016; published 18 May 2016

Copyright (C) 2016 by author and OALib.

This work is licensed under the Creative Commons Attribution International License (CC BY). http://creativecommons.org/licenses/by/4.0/

(c) $\underset{\mathrm{EY}}{\text { (i) }}$ Open Access

\section{Abstract}

The reform of the income distribution system is an important part of the economic system reform, is an important reflection of economic development and social progress, and is an important guarantee for building a harmonious socialist society. The income distribution gap of our country is mainly reflected in the large income gap between urban and rural areas, the large regional income gap, the large income gap between different industries, and the large internal income gap within enterprise, which has directly impacted on the building progress of a well-off society. We must adhere to the principle of income distribution in socialist society: "from each according to his ability, to each according to his work", and increasing the proportion of labor-factor income in the total income year by year, until exceeding the levels of the developed capitalist countries. In addition to salary, the human resources also participate in the distribution of the enterprise's profit in the form of capital. The risk gain obtained from capital is divided into three parts among enterprise, bank and depositor in a certain proportion. The quality level of the most basic product is proportional to the value of the minimum unit of currency. To reform the income distribution system, the country can set up 7 job positions, with each position divided into 7 levels; therefore, the income can be distributed according to the distribution coefficient table, and has an annual increment at the rate of $10 \%$.

\section{Keywords}

Income Distribution Gap, Income Distribution System Reform, Currency Reform, Income Growth Strategy

Subject Areas: Development Economics, Economics, Political Economy

\section{1. 中国收入分配差距的现状}

所谓收入分配差距, 是指在一定社会经济条件下居民之间按照同一货币单位或实物单位所表示的收 
入水平差别, 以及居民收入在社会总收入中占有比重的差别[1]。

新中国成立初期, 我国分配领域占统治地位的“平均主义”思想使得当时的生产效率极为低下。为了 打破“平均主义”，适当合理拉开收入差距，中央推行了“效率优先，兼顾公平”的政策，这一做法对提高 效率、发展经济成效显著, 但随着经济的快速发展, 又出现了收入分配差距过大的现象。收入分配差距 过大影响到社会安定团结的大局, 影响到小康社会的建设[2]。

党的十六大以来, 党和政府高度重视民生问题, 特别是其中的收入分配差距问题, 并颁布了一系列 改革和完善收入分配制度、缩小收入分配差距的政策措施。这对于遏制收入差距不断扩大的趋势起到了 积极的作用, 推动了经济和社会的和谐发展, 但我国收入分配差距持续扩大的趋势并没有得到根本扭转。 2002 年, 中国的基尼系数为 0.45 , 到了 2010 年, 已经达到 0.48 。尽管基尼系数只是一个客观的描述性 标准, 统计中难以将所有实际收入都计入其中, 但它至少从一个方面反映出目前我国收入分配差距已较 为严重, 收入差距呈扩大化的趋势。居民收入差距扩大是经济转轨国家在经济起飞时的普遍趋势, 但收 入差距过大会引发很多社会问题。目前, 我国的收入差距问题已经成为不容忽视的严峻问题, 已直接影 响到全面建成小康社会的进程。具体来说, 我国的收入分配差距主要表现在城乡收入差距、地区收入差 距、行业收入差距和企业内部工资收入差距[2]。

\section{1. 城乡之间收入差距过大}

2002 年以来, 我国城乡居民收入差距不断扩大。2002 年, 城镇居民人均可支配收入与农村居民人均 纯收入的绝对差值为 5227.2 元; 到 2006 年, 这一绝对差值上升为 8172.5 元; 到 2010 年, 这一绝对差值 上升到 13,190 元。从相对差距看, 2002 年以来, 我国城乡居民收入的相对差距虽然在某些年份有缩小的 趋势, 但总体而言, 仍然偏大。2002 年, 我国城镇居民人均可支配收入与农村居民人均纯收入之比为 3.11:1; 2007 年, 这一比例扩大到 3.33:1; 2008 年, 这一比例小幅下降为 3.31:1; 2009 年, 这一比例稳定在 3.31:1; 2010 年, 尽管这一比例再度出现小幅下降, 但依然高达 3.23:1。相对而言, 世界上多数国家的城镇居民 人均可支配收入与农村居民人均纯收入之比处于 1.6:1 以下。可以看出, 我国城乡之间的收入差距是影响 总体收入差距的主要因素。如果再加上城镇居民享受的各种补贴和福利, 城乡居民的实际收入差距还会 更大些[2]。

\section{2. 地区之间收入差距过大}

新中国成立以来, 我国区域经济格局发生了深刻的变化, 从早期的致力于发展内地经济转向优先发 展沿海地区经济。20 世纪 80 年代, 为了适应改革开放的需要, 我国实行重视沿海地区发展的非均衡发 展战略, 东部沿海地区经济迅速走上快速发展的轨道。20 世纪 90 年代, 由于各地区自然条件、社会经 济条件以及国家政策导向的差异, 各地区之间的经济发展水平以及居民收入差距迅速拉大, 并引起了党 和政府的高度重视。自 2002 年 11 月提出全面建设小康社会以来, 我国东中西部地区城乡居民收入水平 都获得了极大的提高, 但无论是从绝对差距来看, 还是从相对差距来看, 地区之间的居民收入水平不断 扩大的趋势并没有从根本上得到改变, 集中表现为东中西部地区间的城镇居民人均可支配收入分配差距 和农村居民人均纯收入分配差距不断拉大[2]。

对于城镇居民人均可支配收入分配差距, 从绝对差距看, 2002 年, 西部地区的城镇居民人均纯收入 为 6710.8 元, 中部为 6424.3 元, 东部为 9355.7 元, 东中西部地区的绝对差距为 2931.4 元, 其中, 城镇 居民人均可支配收入最高的上海市为 13249.8 元, 最低的贵州省 5944.08 元, 其绝对差距为 7305.72 元。 到 2010 年, 东部地区的城镇居民人均纯收入为 $25,743.29$ 元, 中部为 17,302.96 元, 西部为 17,309.03 元, 东中西部地区的绝对差距扩大到 8440.33 元。其中, 城镇居民人均可支配收入最高的上海市为 31838 元, 
最低的贵州省为 14,142.74 元, 其绝对差距为 17,695.26 元。从相对差距看, 2002 年, 东中西部地区的城 镇居民人均纯收入比为 1.39:0.96:1, 城镇居民人均纯收入最高的上海市是最低的贵州省的 2.23 倍; 到 2010 年, 这一比例为 1.49:0.99:1, 其中, 城镇居民人均可支配收入最高的上海市是最低的贵州省的 2.25 倍[2]。

对于农村居民人均纯收入分配差距, 从绝对差距看, 2002 年, 西部地区的农村居民人均纯收入为 1847 元, 中部为 2364 元, 东部为 3546 元, 东中西部地区的绝对差为 1699 元, 其中, 农村居民人均纯收入最 高的上海市为 6223.55 元, 最低的西藏为 1462.27 元, 其绝对差距为 4761.28 元。到 2010 年, 东部地区 的农村居民人均纯收入为 8142.81 元, 中部为 5509.62 元, 西部为 4417.94 元, 东中西部地区的绝对差距 扩大到 3724.87 元。其中, 农村居民人均可支配收入最高的上海市为 13746 元, 最低的贵州省为 3472 元, 其绝对差距扩大为 10274 元。从相对差距看, 2002 年, 东中西部地区的城镇居民人均纯收入比为 1.92:1.29:1, 其中，农村居民人均纯收入最高的上海市是最低的贵州的 4.26 倍; 到 2010 年，这一比例为 1.84:1.25:1, 其中，农村居民人均纯收入最高的上海市是最低的贵州省的 3.96 倍[2]。

\section{3. 行业之间收入差距过大}

2002 年以来, 我国各行业就业者收入水平都有较大的提高, 但提高的程度不尽相同, 导致各行业收 入差距进一步扩大。从行业特点来看, 农林牧渔业、制造业和采掘业等依靠简单劳动和简单技术的行业, 一直是年平均工资和收入较低的行业, 而信息传输、计算机服务和软件业、石油、煤气、电力、电信、 金融、保险等高技术或垄断性行业则是年平均工资和收入较高的行业。其中, 2002-2010 年农林牧渔业始 终是城镇单位就业人员平均工资最低的行业，2002 年、2009 年和 2010 年，金融业是城镇单位就业人员 平均工资最高的行业, 2003-2008 年, 信息传输、计算机服务和软件业收入增幅最高, 是城镇单位就业人 员平均工资最高的行业, 这加剧了平均工资最高行业与最低行业绝对差距不断上升的态势。2002 年, 城 镇单位就业人员平均工资最高的行业的平均工资为 19135 元, 农林牧渔业的平均工资最低, 为 6398 元, 两者相差 12737 元; 2003 年这一差距突破 2 万元, 达到 24013 元; 2005 年这一差距突破 3 万元, 达到 30592 元; 2009 年这一差距突破 4 万元, 达到 42346 元; 2010 年这一差距突破 5 万元, 达到 53429 元,

其中, 最高的金融业为 70146 元, 最低的农林牧渔业为 16717 元[2]。

同时，平均工资最高的行业与最低行业的相对差距也居高不下。2002 年平均工资水平最高的金融、 保险业是平均工资水平最低的农林牧渔业水平的 2.99 倍; 2005 年平均工资水平最高的信息传输、计算机 服务和软件业与平均工资水平最低的农林牧渔业的相对差距达到最大, 为 4.73 倍, 虽然此后几年里这一 相对差距逐年回落到 2010 年 4.2 倍(最高的行业是金融业, 最低的行业是农林牧渔业)的水平, 但与世界 上多数国家行业间差距在 1.5 2 倍左右的水平相比, 这一相对差距仍然过高[2]。

\section{4. 企业内部工资收入差距过大}

生产要素按贡献参与分配是初次分配的原则, 但受劳动力资源丰富、劳动力市场的供给过剩和长期 以来工资水平偏低等因素的影响, 初次分配存在着资本所得不断提高、劳动所得持续下降的趋势。企业 的管理层收入除了不菲的年薪, 还有股权、期权、保险以及各种活动经费, 而大多数普通职工, 特别是 劳动密集型企业以及私营、外资企业和农民工的劳动报酬过低且增长幅度缓慢, 呈现“一低一慢”的特点, 从而使企业内部资本所有者、经营管理者和劳动者之间的收入分配差距不断扩大。据统计, 2010 年上市 公司高管年薪平均值为 66.8 万元, 是当年全国平均工资的 18 倍多, 而城镇私营单位中的住宿餐饮业、 农林牧渔业、公共管理社会组织三个行业中就业人员月均工资收入在 1461 元以下, 不及城镇企业在岗职 工的一半[2]。

数据显示, “十二五”时期, 我国收入分配状况总体向好。2010-2015 年, 全国居民人均可支配收入从 
12520 元增加到 21966 元, 年均实际增长 8.9\%, 快于同期国内生产总值增长。同时, 居民收入差距呈缩 小趋势。2010-2015 年, 全国居民收入基尼系数从 0.481 下降到 0.462。城乡居民收入倍差由 2010 年的 2.99 倍缩小到 2015 年的 2.73 倍。国民收入分配格局有所优化, 居民可支配收入在国民可支配收入中的比重 提高, 劳动报酬在初次分配中的比重提高[1]。

\section{2.中国收入分配差距对经济社会发展的影响}

任何事物都有它的两面性。适度的收入分配差距能产生激励和竞争, 提高效率; 但收入分配差距过 大将会带来一系列负面影响。近年来, 我国城乡收入差距、地区收入差距、行业收入差距以及企业内部 收入差距等都有不同程度的扩大, 这种收入分配差距的客观现状必然对全面建成小康社会的进程产生重 要影响[2]。

\section{1. 适度的收入分配差距对经济社会发展的积极作用}

在处理收入分配差距过大问题的过程中, 我们必须要保持一个清醒的认识, 即适度的收入分配差距 不仅无妨社会稳定, 而且正是建设和谐社会的一个重要前提, 是市场经济体制下全面建成小康社会的必 然选择。因为社会和谐也是一个历史的、动态的命题。每个社会都有其特定的收入分配结构。在当前我国 经济发展的基础上, 要想保证低收入群体的生活不断改善与提高, 那么, 维持市场经济中非均衡的分配结 构, 就是社会和谐与稳定的基础。我国曾试图人为地取消收入分配领域存在的正常差距, 在分配上搞平均 主义, 这实际上是一种更为严重的不公平, 不仅不能充分发挥能力强的劳动者的才能, 而且使能创造更多 财富的人得不到应有的报酬。因此, 保持适度的收入分配差距, 对经济社会的发展具有积极的促进作用, 是经济社会发展的不竭动力。具体来讲, 适度的收入分配差距的积极作用主要表现在以下几个方面[2]。

第一, 适度的收入分配差距有利于克服平均主义, 调动劳动者的积极性和创造性。从现实的情况来 看, 收入增长较快和收入水平较高者多为技术改革和制度创新的推动者和实践者, 收入分配差距的存在 是人们追求技术改革和制度创新最直接和最有力的利益激励。因此, 适度的收入分配差距对形成与社会 主义初级阶段基本经济制度相适应的思想观念和创业机制, 对充分发挥劳动、知识、技术、管理和资本 的活力, 加快全面建成小康社会的步伐, 具有积极的促进作用[2]。

第二, 在劳动、资本、技术、管理等生产要素按贡献参与分配的分配制度下, 要素占有数量的差异 和要素配置合理性的差异所形成的收入分配差距, 是市场合理配置资源的有效激励机制。因此, 适度的 收入分配差距, 有利于资源优化配置, 有利于吸引人才、留住人才、发挥人才的主观能动性[2]。

第三, 适度的收入分配差距有利于形成多层次的购买力及多层次的消费需求结构, 引导企业根据相 应的市场需求进行生产投向, 进而推动产业结构的优化与升级, 提高经济发展的质量, 这客观上也为非 公有制经济、非规范部门的发展创造了条件, 同时有利于拓宽社会就业渠道[2]。

\section{2. 过度的收入分配差距对经济社会发展的消极作用}

收入分配差距过大, 容易加剧社会矛盾, 引发社会不稳定, 危及到经济可持续发展。随着我国收入分 配差距的不断扩大, 其负面影响逐渐显现, 并已成为制约经济社会协调持续发展和全面建成小康社会的 重要障碍。这种负面影响主要表现在对社会稳定、对经济可持续发展以及对和谐社会实现的不利影响[2]。

\subsection{1. 收入分配差距过会大挫伤低收入群众的劳动积极性}

国际上通常认为基尼系数达到 0.4 是收入差距的警戒线, 一旦基尼系数超过 0.4 , 表明财富过度集中 于少数人手中, 社会就可能有发生动乱的危险。2002 年, 我国基尼系数超过 0.4 , 达 $0.45,2010$ 年上升 到 0.48。收入分配差距过大, 一方面会对社会成员参与经济活动的心理产生巨大的冲击, 影响人心所向, 
成为滋生社会不稳定的心理温床。群众对劳动致富带来的正当经营收入差距具有一定承受力, 但对行业 垄断、非法寻租等非正常途径产生的过大的收入差距, 不满情绪强烈。而社会失衡心理蔓延扩散, 将大 大降低劳动者参与生产的积极性, 加剧人们对收入分配不公的不良印象, 进而使社会成员尤其是社会底 层成员的心理承受力极度下降, 参与生产的热情大打折扣, 甚至出现破坏社会信用和经济秩序的行为, 影响社会稳定。另一方面, 收入分配差距特别是绝对贫困的存在, 容易导致社会结构失衡甚至畸形化发 展, 激化社会阶层矛盾, 影响社会稳定。20世纪 90 年代以来, 我国收入分配差距的扩大已经开始伴随 明显的“两极分化”的特点, 如果收入差距持续扩大, 将引发群体性贫困或区域性贫困, 导致群体性矛盾 和和不同利益集团之间的冲突，从而有可能恶化社会秩序，威胁社会稳定[2]。

\subsection{2. 收入分配差距过大不利于经济可持续发展}

正确认识并处理好收入分配差距问题, 不仅关系人民群众切身利益, 体现社会公平正义, 而且关系 经济的良性循环。生产、分配、交换、消费是社会再生产过程的四个环节。生产与分配相互促进、相互 制约。生产决定分配, 分配促进生产。没有经济的持续增长, 分配就没有可靠的物质基础; 没有合理分 配, 增长也会缺乏持久动力和稳定的社会环境。收入分配差距过大对社会经济发展的负面影响具有“连带 效应”, 会对消费和生产产生不利影响, 进而形成影响经济持续发展的恶性循环[2]。

一方面, 收入分配差距过大会对消费产生负面影响。有效需求是经济增长的原动力, 而消费需求的 增长又是与收入增长正相关的。一般来说, 居民收入水平越低, 边际消费倾向越高; 居民收入水平越高, 边际消费倾向越低。目前, 我国居民储蓄呈 “倒二八”分布, 即 $20 \%$ 的高收入储户拥有 $80 \%$ 的储蓄余额, 而 $80 \%$ 的低收入储户仅拥有 $20 \%$ 的储蓄余额。随着收入分配差距的不断扩大, 财富过多地集中在少数高 收入者手中, 但拥有大量财富的高收入者的平均消费倾向较低, 购买力相对过剩; 大量具有潜在消费需 求的低收入者的平均消费倾向较高, 但购买力严重不足, 这种收入水平与平均消费倾向的不协调结合, 必然不能使这种需求转化为有支付能力的有效需求, 造成整个社会平均消费倾向的下降, 进而导致使社 会需求总量有限, 有效需求不足[2]。

另一方面, 收入分配差距过大会对生产产生不利影响。消费和生产是对立统一、互为依存的关系。 没有消费的认可, 生产的价值就难以得到体现; 只有存在一定的消费数量和合理的消费结构, 才会有持 续的生产发展。但我国的现实情况是, 有支付能力的高收入者没有继续扩大消费的意愿, 而有消费意愿 的低收入者又没有支付能力, 这就会导致“生产过剩”。首先, “生产过剩”会使许多实力较弱的中小企业 开工不足, 裁员减产甚至停工破产, 企业利润率下降, 相关利益者收入降低, 进而会影响投资者的投资 信心, 使投资总量减少, 影响经济增长。其次, 投资信心及投资总量的减少会影响社会就业岗位的增加。 就业是民生之本, 对提高低收入群体的收入水平和社会和谐稳定具有关键作用, 而就业岗位的有限增长 使大量低收入者通过就业提高收入的途径受阻。再次, 随着企业投资信心不足、效益下降, 会影响到经 济的健康发展, 而经济的发展状况一定程度上决定着国家财政收入的规模。随着国家财政收入增长的放 缓, 国家财政对低收入者和低收入地区的转移支付力度减弱。这样, 又进一步加剧收入分配的差距, 使 经济发展进入“恶性循环”的怪圈[2]。

\subsection{3. 收入分配差距过大不利于社会和谐稳定}

改革开放以来, 随着我国社会主义市场经济体制改革的不断推进, 我国社会主义建设的各项事业蓬 勃发展, 各阶层民众都享受到了改革开放带来的实惠, 城乡居民收入普遍提高, 生活水平显著改善。与 此同时, 各种社会矛盾也愈发凸显出来。研究表明, 庞大的中等收入阶层对社会收入差距具有较强的调 节功能, 对社会利益的矛盾与冲突具有较强的缓冲功能。在发达国家, 中等收入者所占比重普遍在 60\% $80 \%$ 之间, 呈“中间大、两头小”的橄榄型结构。但从我国目前的收入分配格局看, 中低收入阶层比重仍然偏 
大, 收入分配的基本格局还是金字塔型结构。据测算, 2015 年我国已有 3 亿人(22\%)左右是中等收入者, 而按全面小康社会的标准, 中等收入者比重应该在 50\%以上, 就是说, 为了达到全面小康社会的标准, 从 2016 年起每年平均至少要增加 5 6 个百分点。近年来, 我国这一比例在稳步上升, 但与高速增长的 GDP 相比依然不相匹配, 所期望的 “橄榄型”结构并未出现 , 收入分配差距持续走高的态势未能明显缓解。 收入分配的巨大差距, 容易滋生社会不满情绪, 再加上部分高收入者的收入是通过腐败性、欺诈性、垄 断性等不合理甚至非法手段获得的, 进一步加剧了社会弱势群体的不公平感, 激化了不同收入阶层之间 的冲突与矛盾, 严重影响着社会和谐, 也不利于全面建成小康社会。因此, 如何更好地协调好收入分配 关系, 缩小收入分配差距, 推进社会公平, 即是摆在中国经济社会全面协调发展战略面前的一个重要选 择和挑战, 也是全面建成小康社会的必然要求[2]。

\section{3. 中国收入分配差距过大的根本原因}

中国居民收入分配差距扩大的原因有多种, 具体而言, 可以归纳为以下几种:

1) 历史原因。新中国成立后, 出于种种原因, 中国选择了重工业优先发展的战略。作为一个脱胎于 半殖民地半封建的农业国家, 中国的重工业优先发展战略主要是要通过农产品统购统销制度, 工农业产 品价格“剪刀差”, 低价收购农产品, 将农业剩余转化为工业利润, 再通过严格控制工业部门的工资水平, 把工业利润转化为财政收入。此外, 国家还通过农业税收入和农业储蓄等渠道获得了大量资金积累。根 据有关估计，在 1952 1982 年期间，国家通过价格剪刀差、农业税和农民储蓄净流出三条渠道，从农村 获取 6127 亿元的剩余，相当于 1982 年全部国营企业的固定资产原值。同时，人民公社制度和城乡二元 分割的户籍制度成为政府的长期制度。户籍制度把农村劳动力禁锢于农村和农业，城市职工报酬以及享 受的城市居民各种福利保障远远高于农村可比劳动力，这种城乡隔离的二元经济结构导致改革前城乡居 民较大收入差距的长期存在，也形成了城市居民的利益刚性和改革后的城市偏好[1]。

2) 分配体制的原因。中国现阶段实施的是完善按劳分配为主体、多种分配方式并存、各种生产要素 按贡献参与分配的分配制度。在这种分配体制下，个人收入量的多少，不仅与自己的劳动贡献大小正相 关, 而且还与自己所拥有的物化生产要素多少正相关。是否占有物化生产要素及其量的多少和质的高低, 便成为影响人际间收入差距的重要因素, 不同要素所有者占有要素的数量与质量差异面对个人收入差距 影响巨大。在劳动收入大致均等的条件下, 收入差距主要由财产性收入高低拉大。随着市场经济的建立 和不断完善，人们的财产性积累差距加大，因而财产性收入差别也不断扩大。据统计，2001 年前 20\%的 人拥有 $80 \%$ 的银行存款，而 $80 \%$ 的人仅占银行存款的 $20 \%$; 而在 20 世纪 90 年代，有人根据城镇居民抽 样调查资料推算，30\%的富裕人口占有居民储蓄存款的 47\%[1]。

3) 经济体制转轨的原因。转轨时期的一个重要特征, 就是旧体制虽然已经开始打破, 但新体制还没 有真正建立起来。一些人利用自己所处的有利地位，如掌握重要的经济信息、获得特定的市场准入权, 对重要的、紧缺的商品享有控制权等等, 进行种种形式的设租与寻租活动, 牟取了双轨体制给他们带来 的巨大利益，据为已有。另外在转轨时期，市场机制的作用范围没有得到完全延伸，一些领域里还存在 行业性垄断，由此而产生的垄断收入，其级差部分理应由国家占有，而事实上却没有得到很好的调节， 从而导致了行业之间、部门之间个人收入的极不平衡[1]。

4) 国有企业改革的原因。改革发展至今，国有企业的改革并没有取得根本性突破，国有资产的保值 增值机制、经营人员的收入风险机制，没有真正建立健全，因此造成了国有企业经济效益下滑，国有资 产大量流失。个别企业成了某些人把公有财产转化为私有财产的一种复杂的中介环节, 为少数人暴富提 供了经济来源, 所谓“庙穷方丈富”就是这一情形的生动写照 [1]。

5) 社会保障体系不健全的原因。中国的社会保障制度存在着覆盖面小、资金渠道狭窄、管理服务社 
会化程度低等问题, 无法适应不断发展的新体制需要。我国的社会保障体制是建立在城乡二元隔离基础 上的, 造成了城乡社会保障的巨大差别。城市实行高就业、高补贴的社会保障制度, 大多数居民享有较 高程度的社会保障, 而农村则以传统的家庭保障为主, 其保障水平远低于城市。中国城市中的社会保障 水平是以所有制划线的, 国有企事业单位的职工有较高和较全面的保障, 集体企业和单位的职工所享受 的社会保障则要相对低一些, 个体工商业者则基本不享受社会保障, 这种社会保障待遇差别是失之公允 的。而国有企事业单位职工又恰恰是收入较高的一批人, 国民收入的再分配向这些人倾斜, 更加大了收 入分配差距[1]。

6) 税收调节不力的原因。国际经验证明, 个人所得税在调节社会收入分配方面能够发挥独特的作用, 但目前中国个人所得税制度还不够完善。个人所得税所需要的征管条件目前还不完全具备，从税务部门 本身来讲, 也需要进一步强化征管力度, 严格征收管理。除个人所得税外, 中国还没有建立针对个人财 产存量及其转移进行调节的收益类税种, 比如不动产税、遗产与赠予税。适应现代经济发展和社会变革 需要的社会保障制度既不统一, 又不健全, 在资金筹措上没有采取国际上通行的开征社会保障税的方式, 政出多门, 效益低下。由此造成政府及社会对国有企业下岗职工的安置及其生活困难问题的解决缺乏必 要的财力保障[1]。

改革开放三十多年来, 特别是近十年, 中国居民的收入分配差距越来越大, 一是城乡之间收入差距, 二是地区之间收入差距, 三是行业之间收入差距, 四是企业内部工资收入差距城, 都有扩大的趋势。产 生这种现象的原因有多方面, 其中最根本的原因是：劳动力价格的计量严重脱离以社会必要劳动时间计 量的劳动价值。

当前我国劳动收入在初次分配中出现“三低现象”: 一是劳动收入在 GNI (国民收入)中所占比例低, 工资收入占总收入的比重低; 二是在整个居民收入中，通过劳动报酬分配的比重过小，大量国民财富通 过非规范的途径流入个人手中; 三是劳动要素在企业内部分配中的比重低。虽然生产要素按贡献参与分 配是初次分配的原则，但初次分配存在资本所得不断提高、劳动所得持续下降的趋势。

我国收入分配制度中存在的突出问题是，在参与分配的“劳动、资本、技术、管理”几个主要要素中， 资本、管理在分配中所占比重过大, 劳动所占比例过低, 劳动者积极性受到挫伤, 按劳分配为主体的地 位开始动摇。

\section{4. 收入分配制度改革}

\section{1. 指导思想}

对国民收入的贡献要素可以分为两个, 即劳动和资本, 技术和管理要素可归入劳动要素。必须坚持“各 尽所能, 按劳分配”的社会主义收入分配制度, 逐年提高劳动要素收入在国民收入中的比重, 直到超过发 达资本主义国家的水平。至于劳动要素中的普通劳动、技术劳动和管理劳动, 其收入分配原则应考虑如 下关系：组织之间的竞争，既是产品的竞争，又是技术水平的竞争，更是标准之间的竞争。质量是旗帜， 标准是方向, 技术是发动机, 管理是车轮。质量是大家的事情, 每个人都要关心和重视质量。工资标准 的高低依次为标准相关劳动、技术相关劳动和管理相关劳动。一般工人的劳动为普通劳动, 其收入应视 其与技术的相关程度而确定，高级工人的劳动应视为技术相关劳动。管理劳动应视其与标准和技术的相 关程度而定, 标准管理劳动收入最高, 技术管理劳动收入次之, 普通管理劳动收入最低。

\section{2. 改革措施和准则}

\subsection{1. 总则}

从发展历史看，西方资本主义国家国民收入中由物质资本贡献的份额已从 $45 \%$ 下降到 $25 \%$ ，而劳动 
对国民收入的贡献从 $55 \%$ 上升到 $75 \%$ 。考虑到我国经济发展的实际情况, 我国劳动要素收入在国民收入 中的比例以 $60 \%$ 至 $80 \%$ 为适当, 目前可以定在 $65 \%$ 左右, 以后逐年提高。而资本要素收入所占的比重以 $20 \%$ 至 40\%为适当, 目前可以定在 35\%左右, 以后逐步降低。

提高低收入, 扩大中等收入, 控制高收入。在单位内部, 最高工资和最低工资相差不大于 10 倍, 最 高工资和单位平均工资相差不大于 5 倍。在同一个地区内, 最高工资和最低工资相差不大于 20 倍, 最高 工资和地区平均工资相差不大于 10 倍。保护合法收入，取缔非法收入。

公务员的工资以所在地区(省、市、县、乡、村)的平均工资为基数, 其平均工资不得大于所在地区平 均工资的 2 倍。在地区范围内, 公务员最高工资和最低工资相差不大于 10 倍, 最高工资和地区公务员平 均工资相差不大于 5 倍。

在任何组织内部, 中共党员的工资以所在组织相同岗位的平均工资为基数, 其平均工资不得大于该 一级岗位的平均工资。

以上要求由各地方人大颁布条例进行具体规定, 并由审计部门每年进行审计, 且责令不符合要求的 单位限期整改。

\subsection{2. 资本的增值和收入}

马克思说过, 劳动, 只有劳动, 才是创造社会财富的唯一源泉。那么, 为什么资本会增值呢? 我们 都知道, 根据马克思的劳动价值学说, 任何商品的价值都是由创造该商品的社会必要劳动时间决定的, 而资本是对社会必要劳动时间的货币度量, 是与当期的社会必要劳动量对应的。随着时间的推移, 当技 术进步、制度安排和结构发生改善、劳动者素质和技能提高时, 生产商品的社会必要劳动时间会缩短, 那么与原来的社会必要劳动时间对应的劳动量可以创造出更多的社会财富, 与资本对应的原社会必要劳 动的量也可以对应更多的社会财富, 资本便增值了。那么, 资本增值的幅度应该是多少呢? 应该说, 劳 动生产率的增长率中人均产品产量的增长率是多少, 资本就应该增值多少。

资本所获得的收入, 除了劳动生产率中人均产品产量提高带来的资本增值以外, 还包括资本的风险 收入和资本家的部分劳动收入, 所以资本的收益率要比劳动生产率的提高率中人均产品产量的增长率高 一些, 这也是合理的。

资本所获得的收入，必须在储户、银行、企业(资本使用者)三者之间合理进行分配。劳动生产率提高 所带来的资本增值, 应根据三者的贡献大小有差别地进行分配, 储户得大头, 企业(资本使用者)得中头, 银行得小头; 风险收入则根据三者所承担的风险大小有差别地进行分配, 一般情况下, 企业(资本使用者) 得大头, 银行得中头, 储户得小头。通货膨胀应由三者平均承担。所以, 银行存款利率应大于全社会平 均劳动生产率中产品产量的增长率的三分之一加上通货膨胀率的三分之一的和。而全社会平均劳动生产 率中产品产量的增长率等于 GDP 的增长率减去投入劳动的增长率和平均质量水平的增长率。比如说, 通 货膨胀率为 $2 \%, \mathrm{GDP}$ 增长率为 $7 \%$, 投入劳动的增长率为 $1 \%$, 平均质量水平的增长率为 $2 \%$, 则:

社会平均劳动生产率中产品产量的增长率 $=7 \%-1 \%-2 \%=4 \%$;

存款利率 $>1 / 3 \times 2 \%+1 / 3 \times(7 \%-1 \%-2 \%)=2 \%$;

资本的增值率 $\approx 1 / 3 \times 2 \%+1 / 3 \times(7 \%-1 \%-2 \%)=2 \%$;

银行存贷差 $<1 / 3 \times 2 \%+1 / 3 \times(7 \%-1 \%-2 \%)=2 \%$ 。

\subsection{3. 对人力资源的考虑}

目前, 人力资源仅被当作与其它三种生产要素(资本、技术、管理)对等的要素, 人力资源成本(工资 等)作为管理成本之一计入财务考虑。且从我国的情况看, 工资收入在国民收入中所占的比重很低, 仅 35\% 左右。实际上, 人力资源不仅是不同于实物资本的独立要素, 同时也是一种特殊资本, 其对经济增长的 
贡献远大于实物资本。所以在投资中, 不仅包括实物资本额, 而且应当包括人力资本额。那么, 人力资 本怎样作价呢? 对中国而言, 可根据个人受教育程度、工作能力和对企业的贡献不同进行作价, 将人力 资本根据自己在整个企业投资额(总的实物资本额 + 总的人力资本额)中所占的比例参与企业利润的等 权分配。所以，人力资源除得到工资外，还以资本的形式参与企业利润的分配。

在宏观经济模型中，投资额 I 也应等于实物资本额 + 人力资本额的总和。即为保持国民经济增长， 多投入劳动和多投入实物资本，具有同等的效用。于是，员工和出资人会共同关心企业的利润，不仅劳 动和资本的矛盾解决了, 充分就业也是比较容易实现的。拿我所在的东方锅炉来说, 最近十多年来, 职 工平均年工资收入为 5 10 万元现行人民币不等, 考虑到职工的年龄和工龄结构, 假设平均工龄为 10 年, 那么东方锅炉职工的平均工资总收入为 50 100 万元现行人民币不等。所以，不妨将东方锅炉职工平均每 人按 80 万元现人民币作价。东方锅炉的实物资本净资产为 50 亿元现人民币，其当年(2014 年)的净利润 为 8.5 亿元现人民币, 而其员工总数为 4000 人, 平均每人按 80 万元现人民币作价, 即企业总人力资本 额为 32 亿元现人民币, 那么企业员工应分得总的利润份额 $\left(R_{h}\right)$ 如下:

$$
R_{h}=\frac{32}{50+32} \times 8.5=3.32 \text { 亿元现人民币。 }
$$

对中国而言，可根据个人受教育程度、工作能力和对企业的贡献不同，对人力资本作价 50 100 万元 现行人民币。人力资本根据自己在整个企业投资额(总的实物资本额 + 总的人力资本额)中所占的比例参 与企业利润的等权分配。

\subsection{4. 企业收益的分配}

假设一个企业投入实物资本为 $C_{m}$, 人力资本 $C_{h}$, 企业增加值为 $V_{a}$, 增值税税率为 $t_{a}$, 企业所得税 税率为 $t_{i}$, 资本所获得的风险收益为 $R$, 在企业(资本使用者)、银行、储户三者之间按一定的比例(比如 $70 \%+20 \%+10 \%)$ 分成，则有:

$$
\begin{gathered}
3.2 \% \times C_{m}<0.7 R<\frac{C_{m}}{C_{m}+C_{h}} \times V_{a} \times\left(1-t_{a}\right) \times\left(1-t_{i}\right) \\
0.91 \% \times C_{m}<0.2 R<\frac{2}{7} \times \frac{C_{m}}{C_{m}+C_{h}} \times V_{a} \times\left(1-t_{a}\right) \times\left(1-t_{i}\right) \\
0.46 \% \times C_{m}<0.1 R<\frac{1}{7} \times \frac{C_{m}}{C_{m}+C_{h}} \times V_{a} \times\left(1-t_{a}\right) \times\left(1-t_{i}\right)
\end{gathered}
$$

每个年度结算后, 企业应根据从银行贷款的数量占其投入资本的比例, 将一定数量的资本收益返还 给银行。假设企业从银行贷款的数量为 $L$, 则有:

$$
\text { 企业给银行的返还额 }=0.3 R \times L / C_{m} \approx \frac{3}{7} \times \frac{C_{m}}{C_{m}+C_{h}} \times V_{a} \times\left(1-t_{a}\right) \times\left(1-t_{i}\right) \times \frac{L}{C_{m}}
$$

银行再将其中的 $1 / 3$ 按储户存款额 $(d)$ 占总存款额 $(D)$ 的比例返还给储户, 即有:

$$
\text { 银行给储户的返还额 }=0.1 R \times L / C_{m} \times d / D \approx \frac{1}{7} \times \frac{C_{m}}{C_{m}+C_{h}} \times V_{a} \times\left(1-t_{a}\right) \times\left(1-t_{i}\right) \times \frac{L}{C_{m}} \times d / D
$$

企业增加值中分配给全体劳动者额度为: $\frac{C_{h}}{C_{m}+C_{h}} \times V_{a} \times\left(1-t_{a}\right) \times\left(1-t_{i}\right)$ 


\subsection{5. 企事业单位员工收入分配原则}

对全国所有的公有制及其它所有制企事业单位来说, 其员工的劳动包括普通劳动、技术劳动和管理 劳动。工资标准的高低依次为标准相关劳动、技术相关劳动和管理相关劳动。一般工人的劳动为普通劳 动, 其收入应视其与技术的相关程度而确定, 高级工人的劳动应视为技术相关劳动。管理劳动应视其与 标准和技术的相关程度而定, 标准管理劳动收入最高, 技术管理劳动收入次之, 普通管理劳动收入最低。 此外, 应对承担急难险重任务的员工有所倾斜, 增加工资或进行补助。事业单位(如教学和科研单位等) 的教学和科研劳动被视为技术劳动, 其余均为普通劳动和管理劳动。

\section{5. 货币改革与收入分配}

\section{1. 币值与产品质量}

从理论上讲, 货币最小单位的价值代表了最基本(价格最低)产品的价值, 所以, 最基本产品的质量水 平与货币最小单位的价值成正比, 哪一个国家或地区货币最小单位的价值越高, 则其产品平均质量水平 越高。从实际情况看, 币值较高的发达国家或地区, 其产品质量水平的确更高。例如, 英国、美国、德 国和以前的日本, 他们的产品质量确实高人一筹。当下, 日元大幅贬值, 表明日本产品的质量也在大幅 下降。

对中国而言, 解放前一个现大洋面值为一元, 而现在要卖到 100 多元人民币。也就是说, 中国货币 的价值从 1949 年到时现在贬值了 100 多倍, 解放前的一个小钱就能相当于现在的 1 元人民币。当然, 现 在最便宜的单件产品能卖到 0.1 元人民币左右。所以, 可以认为, 现在的产品平均质量水平只相当于 1949 年前的 $1 / 10$, 中国产品的质量水平是逐年退步的。

要使现在的平均产品质量水平与 1949 年前相当, 就有必要将现在的人民币贬值 10 倍。为了给平均 产品质量水平的提高(经济增长)留有余地, 比如说, 到 2049 年建国 100 周年时, 我国的产品平均质量水 平较 1949 年前的水平提高 10 倍, 则有必要将现行的人民币贬值 100 倍。所以, 我国可以发行新的人民 币, 其面值为 1 分至 10 元不等, 同时废除现行人民币, 并规定现行人民币以 100 元对 1 元的比例与新人 民币兑换。同时，通过国际群商说服世界其它国家和地区采取相同的政策。

\section{2. 货币改革与收入分配}

1) 将现有人民币纸币贬值 100 倍, 发行新的人民币, 面额为 1 分至 10 元。

2) 进行收入分配改革, 全国设 7 个岗位, 同一岗位设 7 个岗次, 其分配系数见表 1 。

不同地区, 不同单位, 基数有所不同, 从 1.0 到 2.0 , 由各地区和各单位具体掌握。

表 1. 全国收入分配系数

\begin{tabular}{lllllll}
\hline 3.00 & 3.60 & 4.32 & 5.18 & 6.22 & 7.46 & 9.00 \\
2.49 & 3.00 & 3.60 & 4.32 & 5.18 & 6.22 & 7.46 \\
2.07 & 2.49 & 3.00 & 3.60 & 4.32 & 5.18 & 6.22 \\
1.73 & 2.07 & 2.49 & 3.00 & 3.60 & 4.32 & 5.18 \\
1.44 & 1.73 & 2.07 & 2.49 & 3.00 & 3.60 & 4.32 \\
1.20 & 1.44 & 1.73 & 2.07 & 2.49 & 3.00 & 3.60 \\
1.00 & 1.20 & 1.44 & 1.73 & 2.07 & 2.49 & 3.00 \\
\hline
\end{tabular}




\section{3. 收入增长战略}

2012 年, 联合国国际劳工组织(ILO)对全球 72 个国家和地区人均月收入做了最新统计, 其中, 中国 员工月平均工资为 656 美元，约合现人民币 4134 元，即新人民币 41.34 元。

如果我国的新货币发行和收入分配方案从 2018 年 1 月开始实施, 按人均工资每年 7\%的增速, 那么, 2017 年底, 我国员工的平均工资应为现人民币 $4134 \times 1.07^{5}=5798$ 元, 即新人民币 57.98 元。我们不妨将 2018 年的员工月平均工资定为新人民币 60 元, 对应于收入分配系数的中位值 3.00。所以, 我们可以将 2018 年我国的最低工资和最高工资分别定为 20 元新人民币/月和 360 元新人民币/月, 最低和最高小时工 资分别为: 0.11 元新人民币/时和 2.04 元新人民币/时。从 2019 年开始, 以上数据按每年 $10 \%$ 的速度递增。 当然, 我们必须不断改进我们的工作质量, 保证我国产品质量的平均水平以大于每年 $10 \%$ 的速度改善。

2016 年 5 月 5 日修改于自贡

\section{参考文献 (References)}

[1] 百度百科. 收入分配差距[EB/OL].

http://baike.baidu.com/link?url=5tIXYpCMRt7b58g98L5QmRHsmvfy9dOP6NWxqccakwMV2W9jGQfM5m5hQfqT F6VbjCMo35pcx r7FQQqgZmtEq

[2] 人民网-理论频道. 中国收入分配差距现状及其影响[EB/OL].

http://theory.people.com.cn/n/2012/1213/c353107-19888034.html, 2012-12-13.

http://theory.people.com.cn/n/2012/1213/c353107-19888034-2.html, 2012-12-13.

http://theory.people.com.cn/n/2012/1213/c353107-19888034-3.html, 2012-12-13.

http://theory.people.com.cn/n/2012/1213/c353107-19888034-4.html, 2012-12-13. 